\title{
Paleoseismological analysis of the Rurrand fault near Jülich, Roer Valley graben, Germany: Coseismic or aseismic faulting history?
}

\section{K. Vanneste \& K. Verbeeck}

Royal Observatory of Belgium, Ringlaan 3, B-1180 Brussel, Belgium

Corresponding author: Dr. Kris Vanneste, Royal Observatory of Belgium, Ringlaan 3

B-1180 Brussel, Belgium, tel. +32-2-3730280 / fax +32-2-3730339

email: kris.vanneste@oma.be

Manuscript received: 15 December 2000; accepted: 5 July 2001

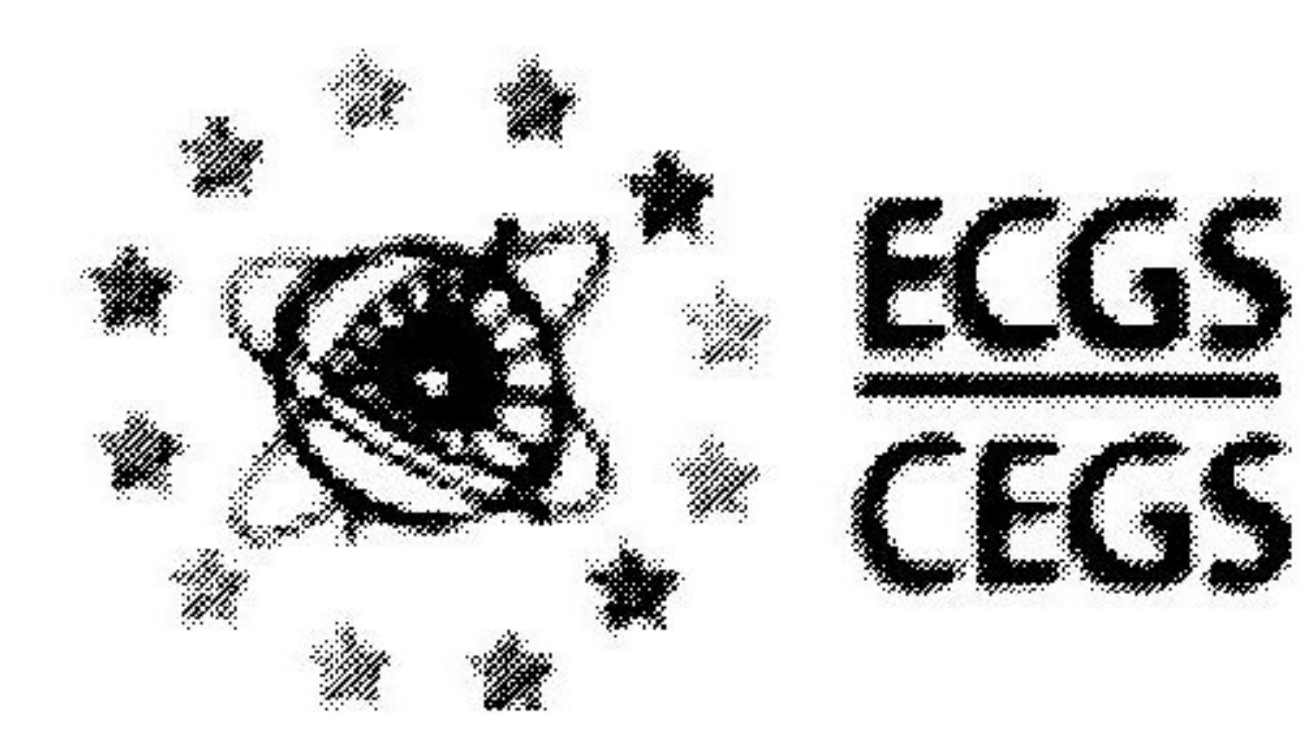

\begin{abstract}
A first trench has been excavated for paleoseismological analysis in the German part of the Roer Valley graben, which has experienced several historical earthquakes with a maximum intensity up to VIII on the MSK-scale. The trench has exposed the Rurrand fault as a complex fault zone with at least five separate, SW-dipping, normal fault strands displacing an early Pleistocene terrace of the Rhine river by more than $7 \mathrm{~m}$. The major part of the observed deformation was produced during or after deposition of an overlying unit of stratified loess of middle Weichselian to probably Saalian age. The faulting history is shown to be episodic, with different fault strands active at different times. Growth faulting that would be indicative of continuous, aseismic fault motion has not been observed. Our stratigraphic control is not sufficient to constrain the timing and to provide evidence of the coseismic nature for each observed fault displacement. However, two units of structureless, gravelly loess are interpreted as the result of extensive solifluction triggered by two large surface-rupturing events. This is suggested by the position of these units, which is controlled by the main faults, and by their remarkably young age ( $<400$ cal. BC), indicated by radiocarbon and OSL datings and by the presence of historic brick fragments. At least two faults show moderate activity that is even younger. Our interpretation is not in agreement with earlier hypotheses that ongoing vertical movements of circa $1 \mathrm{~mm} / \mathrm{a}$ in the German part of the Lower Rhine graben are the result of aseismic fault creep, but is in line with the results of similar investigations on the southwestern border fault of the Roer Valley Graben in Belgium, which demonstrates the need for further paleoseismological research in this region. The Rurrand fault is presently experiencing aseismic slip on its superficial portion, induced by extensive groundwater lowering for mining purposes. This ongoing deformation seems to be expressed in the trench as diffuse bundles of anastomosing cracks extending up to, and in some cases even into the plough zone, rather than as sharp fault planes which are typical of older, tectonic fault movements.
\end{abstract}

Keywords: colluvial wedge, induced fault slip, Lower Rhine graben, surface rupturing, solifluction, trenching

\section{Introduction}

The borderland of Germany, the Netherlands and Belgium is transected by a series of NW-SE trending grabens and horsts known as the Lower Rhine graben (LRG) system, a rift system which was initiated during the Late Oligocene (Geluk et al., 1994). Although its present-day seismicity is moderate, this area represents one of the seismically most active zones in intraplate north-western Europe (Fig. 1).
The most active structure is the Roer Valley graben (RVG), bordered by the Feldbiss fault zone to the SW and by the Peelrand/Rurrand faults to the NE. Since 1755, the RVG has experienced five earthquakes with magnitude $M_{L}>5.0$ (Ahorner, 1994; Fig. 1). The largest event recorded during the $20^{\text {th }}$ century was the $M_{\mathrm{W}} 5.4\left(\mathrm{I}_{0}=\right.$ VII MSK) Roermond, the Netherlands, earthquake, which occurred on the Peelrand fault in 1992 (Camelbeeck et al., 1994; Pelzing, 1994). The strongest earthquake in the catalogue took place in 


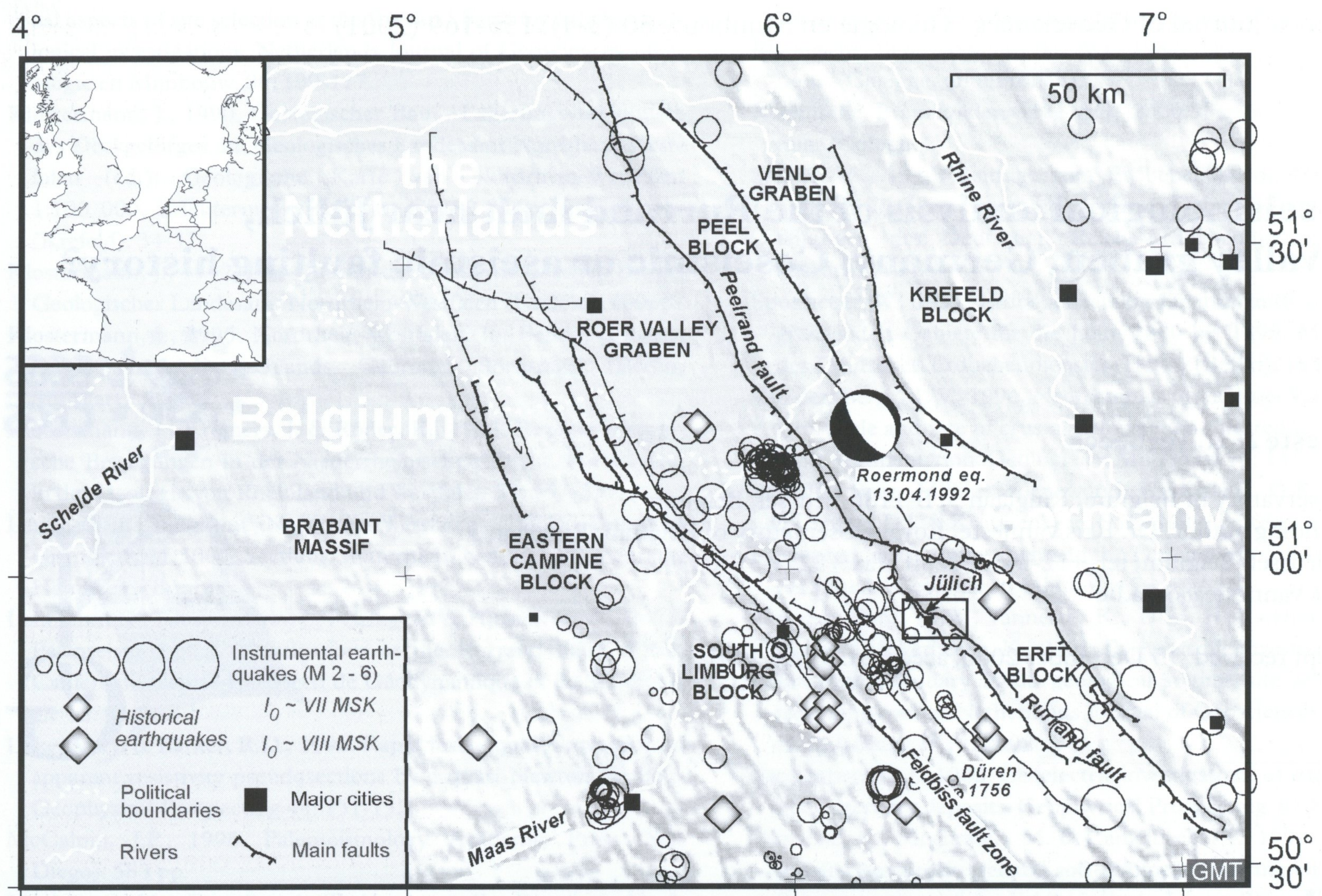

Fig. 1. Seismotectonic map of the Lower Rhine graben area showing location of major Quaternary faults, instrumental seismicity (Royal Observatory of Belgium catalogue 1911-1999) and historically documented earthquakes (Alexandre, 1990, 1994). Rectangle indicates location of study area near Jülich, Germany. Shaded relief map derived from GTOPO30 global topography data set.

1756 in the vicinity of Düren, Germany, with intensity $\mathrm{I}_{0}=$ VIII MSK (Ahorner, 1994) and estimated magnitude $M_{\mathrm{S}}=5.4$ (Seismic Hazard Working Party, 1993). However, the historical record is only considered complete since about 1350 AD (Alexandre \& Kupper, 1997). This is not sufficient to properly assess the seismic hazard in an active intraplate domain such as the Lower Rhine graben, where long-term strain rates are well below $1 \mathrm{~mm} / \mathrm{a}$ (e.g. van den Berg, 1994: $0.06 \mathrm{~mm} / \mathrm{a}$; Geluk et al., 1994: $0.08 \mathrm{~mm} / \mathrm{a}$; Meghraoui et al., 2000: $0.07-0.1 \mathrm{~mm} / \mathrm{a}$ ), and the seismic cycle correspondingly spans several $10^{3}-10^{4}$ years (Scholz, 1990).

Levelling profiles conducted prior to 1960 across the Peelrand and other boundary faults in Germany indicated an ongoing relative vertical strain rate of 1 $\mathrm{mm} / \mathrm{a}$ between tectonic blocks on either side of those faults (Ahorner, 1968). Since the mean seismotectonic dislocation rate determined from the seismic catalogue was found to be five times smaller $(0.23 \mathrm{~mm} / \mathrm{a})$, it was concluded that aseismic fault slip is presently occurring on these faults, and that episodic aseismic slip represents the dominant slip mode in the Lower Rhine graben area (Ahorner, 1975). The possible occurrence of larger earthquakes than are presently known was thus dismissed. However, the horizontal resolution of the levelling data is generally too low to determine if these ongoing block movements are confined to the fault plane (slip), or if they represent strain accumulation over a broader zone. Both alternatives have radically different implications for the present-day seismic hazard. Unfortunately, extensive groundwater extraction related to open-cast browncoal mining has induced superficial differential movements on most faults in the German part of the LRG of the order of $10 \mathrm{~mm} / \mathrm{a}$ during the last 40 years (Schaefer, 1999). These induced movements are outpacing tectonic deformation by at least an order of magnitude, and make it impossible to investigate the tectonic strain in more detail by geodetic means.

One way to determine if fault movement in the LRG is aseismic or coseismic in nature is to search for traces of past large earthquakes in the youngest stratigraphic record along the presumably active faults. Following the finding of evidence for past coseismic surface faulting along the Bree segment of the SW border fault of the RVG in Belgium (Camelbeeck \& Meghraoui, 1996, 1998; Meghraoui et al., 2000), paleoseismological investigations were carried out in the German part of the RVG in the framework of the ECproject PALEOSIS. In 1999, this project resulted in the excavation of a trench across the Rurrand fault a 
few $\mathrm{km} \mathrm{SE}$ of the town of Jülich (Fig. 1). The geomorphological and geophysical research involved in the site selection are reported by Hinzen et al. (this volume) and Lehmann et al. (this volume), respectively. In addition, Lehmann et al. (this volume), here further denoted as LKP-2001, describe the tectonic and geologic framework of the study area, the methodology used, and the stratigraphy and general faulting pattern encountered in the trench. See their Figure 2 for a more detailed location map. The trench was excavated across a pronounced morphological scarp $( \pm 12$ $\mathrm{m}$ high and max. slope of $9^{\circ}$ ), without evidence of a frontal scarp (Hinzen et al., this volume).

A broad and complex fault zone was exposed (Fig. 2), consisting of several normal fault strands dipping $70^{\circ}-75^{\circ} \mathrm{SW}$, and displacing fluvial sands and gravel of Pliocene to Early Pleistocene age and overlying loess deposited during the Weichselian (117 - $10 \mathrm{ka} \mathrm{BP})$ and probably also the Saalian (185 - $130 \mathrm{ka}$ BP) glacial periods. A general map of the entire NW trench wall is presented in LKP-2001. Our contribution to the project consisted of a more detailed mapping and analysis of the main fault zone, which was situated in a c. 15-m-wide zone about halfway the overall escarpment. The objective was to look for evi- dence of the faulting behaviour (coseismic or aseismic), if possible to identify and date individual paleoearthquakes, and to separate the influence of modern induced fault motion from the tectonic signal. Below we describe in turn the stratigraphic framework and dating control, detailed observations of the faulting geometry, the inferred history of faulting, and finally our observations concerning the expression of modern induced fault movements in the trench record.

\section{Stratigraphy of the main fault zone}

Fig. 3 shows a detailed map of the portion of the NW trench wall between 40 and $57 \mathrm{~m}$. This portion corresponds to the main fault zone, containing the best-defined fault strands affecting the youngest sediments and soils. The exposed sediments are mainly fluvial terraces of the Rhine river, and younger reworked loess deposits. An extensive description of the trench stratigraphy can be found in LKP-2001. We use the same stratigraphic scheme, with the important difference that we distinguish three additional stratigraphic units (our units 7-9) at the downslope end of the trench. LKP-2001 have indicated the limits of these

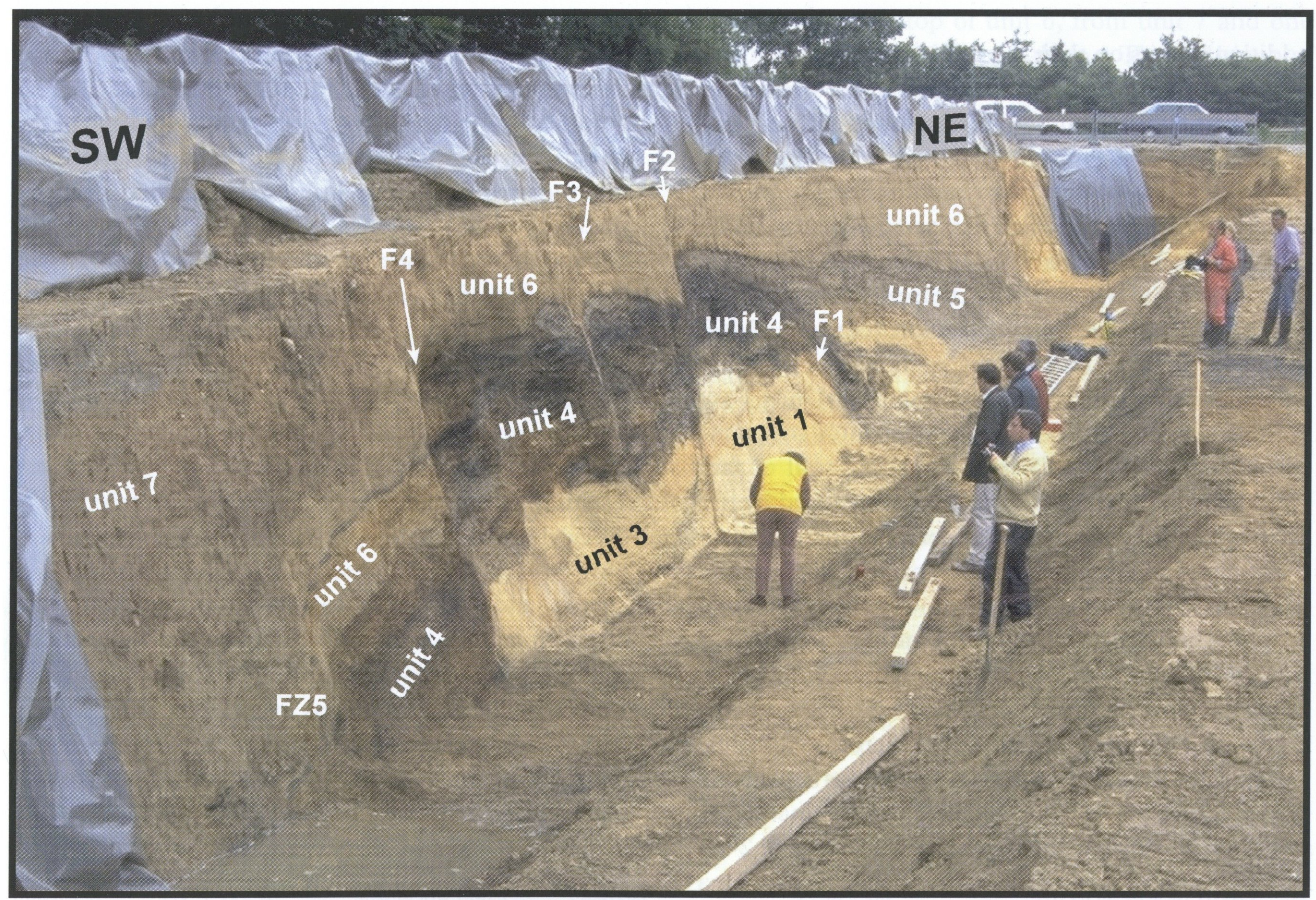

Fig. 2. Photograph of NW wall of trench at site Jülich-Stallbusch. The Rurrand fault corresponds to a zone of several normal fault strands that are clearly expressed by the displacement of a dark-coloured gravel layer (unit 4). 


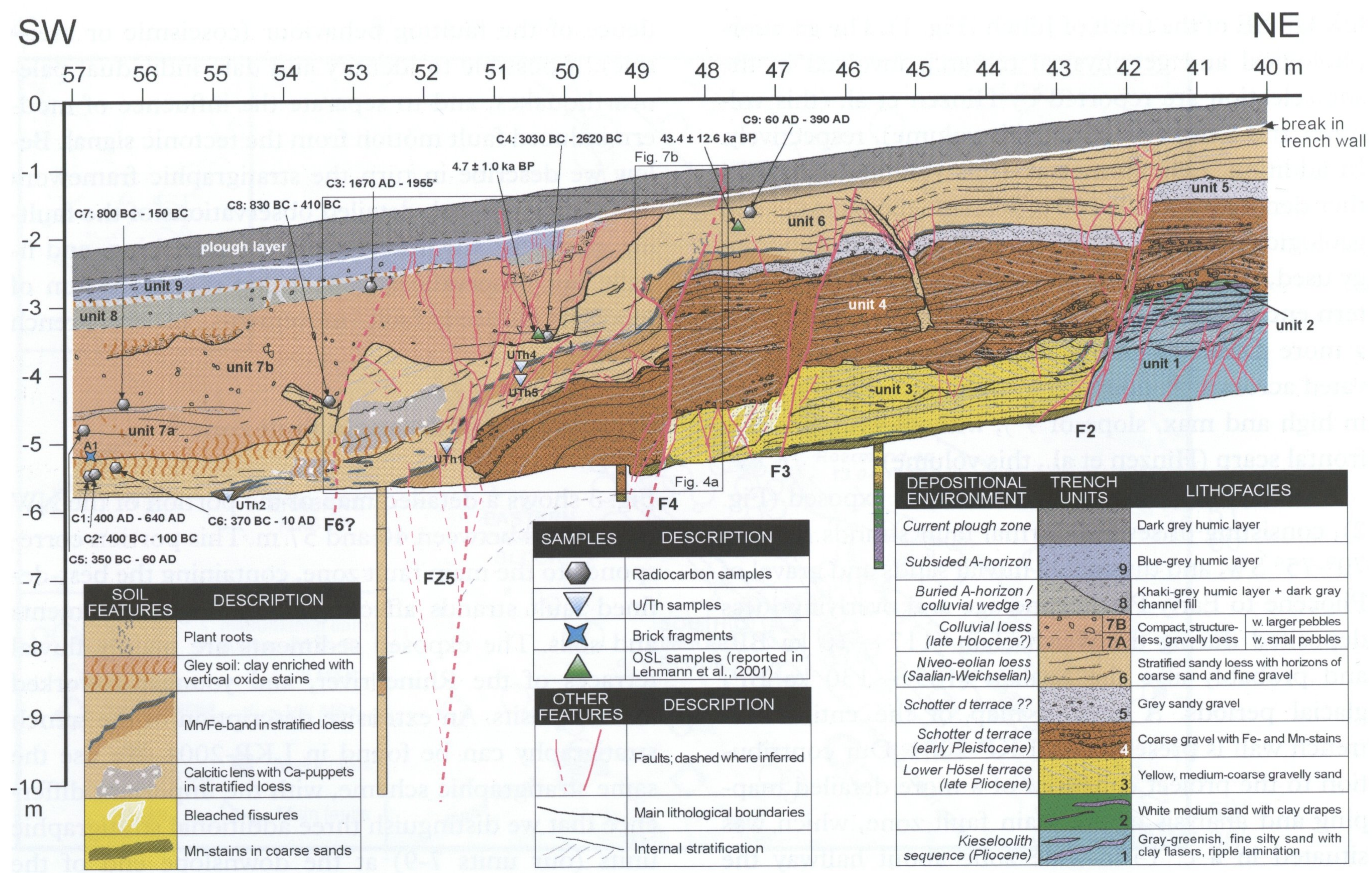

Fig. 3. Detailed geological section of the main fault zone exposed on the NW trench wall at site Jülich-Stallbusch. See Lehmann et al. (this volume) for exact location. Indicated are position of different fault strands (F1-6), stratigraphic units (1-9), and dating samples.

additional units on their trench drawing too (compare their Fig. 7 with our Fig. 3), but consider them to be part of one single unit that also includes our unit 6 .

Unit 1 , in the footwall of fault $F 2$, represents the oldest deposits in the main fault zone. The unit is composed of grey-greenish fine sand with clay flasers and is characterised by ripple lamination. Based on their heavy mineral spectrum, these sands can be correlated to the Pliocene Kieseloolith sequence (LKP2001). Unit 1 is overlain by a thin layer of white medium sand with clay horizons (unit 2). Units 1 and 2 are juxtaposed against yellow, medium to coarse, gravelly sands of unit 3 in the hanging wall of fault F2. The lower part of this unit is characterised by parallel bedding, whereas the upper part mainly shows cross-bedding. Heavy mineral analyses suggest that unit 3 sands correspond to the Lower Hösel terrace of late Pliocene age (LKP-2001). Unit 4 is a striking, \pm 1.5 -m-thick body of coarse, rounded gravel which is entirely coloured brown and black by $\mathrm{Fe}$ - and $\mathrm{Mn}$ stains. The unit is the result of the erosional/depositional activity of a large fluvial system, as attested by the presence of several channels, its distinct crossbedding, and its erosional contact with units 1,2 and 3. LKP-2001 attribute this deposit to the early Quaternary Gravel $\mathrm{d}$ sequence $( \pm 1.7 \mathrm{Ma}$ ), though the heavy mineral signature is not unambiguous. Unit 4 is overlain by another unit of coarse, more sandy gravel that is not stained, but grey in colour (unit 5). This unit deeply incises into the older gravel upslope of the mapped section (see Fig. 2). Of particular interest is that the top of unit 5 is almost horizontal over the entire section. According to LKP-2001, unit 5 probably belongs to the Gravel $\mathrm{d}$ sequence as well, although the absence of $\mathrm{Fe}$ - and $\mathrm{Mn}$-staining seems to suggest that deposition of units 4 and 5 was separated by a relatively long period of weathering and translocation of $\mathrm{Mn}$ - and $\mathrm{Fe}$-ions. In addition, the upper part of unit 5 contains some lenses of loess which is very similar to the overlying sediment.

Unit 6 is a thick unit of light-brown, stratified loess, everywhere overlying the coarse gravel deposits of units 4 and 5, and containing several horizons of coarse sand and fine gravel. This deposit is interpreted as an aeolian sediment that was syngenetically reworked by slope wash, probably fed by snowmelt ('niveo-aeolian', Gullentops et al., 1981). The thickness of unit 6 decreases from $3.5 \mathrm{~m}$ upslope of the mapped section to $0.65-1.25 \mathrm{~m}$ in the fault zone. A hand boring indicates, however, that the loess is substantially thicker ( $>6 \mathrm{~m}$, without reaching the base) downslope of the main fault zone (Fig. 3). LKP-2001 report two OSL-dates for this unit, one $(67.3 \pm 13.4$ ka BP) upslope of our section, the other $(43.4 \pm 12.6$ 
ka BP) near m 47.5 (see Fig. 3), indicating an Early to Middle Weichselian age. Loess deposits of Saalian age (185 - $130 \mathrm{ka} \mathrm{BP})$, known from surrounding areas (e.g. Juvigné et al., 1996), may be preserved in the hanging wall below the trench bottom. The glacial origin of unit 6 is testified by the presence of a subvertical fissure interpreted as an ice-wedge cast extending down into unit 4 gravel, and filled with loess laminated parallel to the edges (Fig. 3, near $45.5 \mathrm{~m}$ ). Post-depositional weathering has resulted in complete decalcification (except for a small patch just downslope of the main fault zone, 52-54 m in Fig. 3) and development of a striking black-and-brown band of $\mathrm{Mn}$ - and $\mathrm{Fe}$-stains.

In the downslope part of the trench, the stratified loess of unit 6 is deeply incised by a thick unit of brown-coloured, structureless loess containing a significant amount (estimated at 5-10 vol. \%) of dispersed gravel (unit 7). This unit is interpreted as a colluvial deposit, resulting from solifluction (slow downslope movement of surface layers) of the underlying unit 6 . Solifluction of these loess deposits is indicated by downslope rotation of several originally subvertical features, such as the ice-wedge cast near $45.5 \mathrm{~m}$, fault plane $\mathrm{F} 4$ near $48.5 \mathrm{~m}$, and some FZ5 faults near 51.5 and $52.5 \mathrm{~m}$ (Fig. 3). The solifluction probably evolved into a true slope failure which caused upper loess and gravel (not preserved in the section) to mix up and incise into lower-lying loess layers, resulting in strong erosion of unit 6 over the entire section, and in deposition of the chaotic unit 7 downslope. This solifluction plays an important role in our reconstruction of the faulting history, as described further on. Unit 7 is divided into two parts, a lower, 70-cm thick subunit (7a) containing only small $(\varnothing<2 \mathrm{~cm})$ pebbles, and an upper, more than $1-\mathrm{m}$ thick subunit (7b) which is characterised by coarser gravel. These subunits are separated by a thin, discontinuous layer of faintly stratified loess without gravel, suggesting that the colluvial loess was deposited in two separate phases. The upper part of unit $7 \mathrm{~b}$ also contains some channel-like accumulations of coarse gravel that were probably concentrated from the colluvial loess by a small local stream. LKP-2001 obtained one OSL-date from the base of unit $7 \mathrm{~b}$, yielding a remarkably young age of $4.7 \pm 1.0 \mathrm{ka} \mathrm{BP}$ (see Fig. 3 for position of sample). The entire unit 7 is affected by soil development (B-horizon, gley).

The stratigraphy above unit 7 is not so well-defined. We discern two grey-coloured, humic-rich layers, units 8 and 9 , forming a transition to the plough zone. They are limited to the downslope part of the trench (downslope of $50 \mathrm{~m}$, Fig. 3) and resemble buried A-horizons. A \pm 40 -cm-thick plough layer truncates the stratigraphy over the entire length of the trench. Part of the section may be missing by anthropogenic surface modification.

\section{Dating results}

In addition to the three OSL-samples reported by LKP-2001, we have collected several small charcoal samples from the top of unit 6 , from unit 7 and one from unit 8 for radiocarbon dating. The positions of these samples are indicated in Fig. 3, and the dating results are summarised in Table 1 . The dates from the top of unit 6 and from unit 7 appear to be very young, and are all contained between c. 2000 and 4300 a BP, which is in general agreement with the OSL-date (4.7 $\pm 1.0 \mathrm{ka} \mathrm{BP}$ ) obtained from unit $7 \mathrm{~b}$ by LKP-2001. A late Holocene age of unit 7 is also confirmed by the finding of two brick fragments, probably of Roman

Table 1. AMS radiocarbon dating results for samples from units 6,7 and 8 in Jülich trench.

\begin{tabular}{|c|c|c|c|c|c|}
\hline Sample ID & Lab ID & Trench unit & Type of material & AMS age (a BP) & Calibrated age $(2 \sigma)$ \\
\hline Jülich-C3 & NZA-1 1244 & unit 8 & charcoal & $35 \pm 60$ & $\begin{array}{l}1670 \mathrm{AD}(25.2 \%) 1760 \mathrm{AD} \\
1800 \mathrm{AD}(70.2 \%) \text { modern }\end{array}$ \\
\hline Jülich-C4 & NZA-11246 & base unit $7 b$ & charcoal & $4265 \pm 60$ & $\begin{array}{l}3030 \mathrm{BC}(56.7 \%) 2830 \mathrm{BC} \\
2820 \mathrm{BC}(37.6 \%) 2660 \mathrm{BC} \\
2650 \mathrm{BC}(1.1 \%) 2620 \mathrm{BC}\end{array}$ \\
\hline Jülich-C7 & NZA-1 1240 & base unit $7 b$ & charcoal & $2305 \pm 60$ & $\begin{array}{l}800 \mathrm{BC}(1.5 \%) 700 \mathrm{BC} \\
550 \mathrm{BC}(93.9 \%) 150 \mathrm{BC}\end{array}$ \\
\hline Jülich-C8 & NZA-1 1516 & base unit $7 b$ & charcoal & $2560 \pm 70$ & $\begin{array}{l}830 \mathrm{BC}(90.2 \%) 480 \mathrm{BC} \\
470 \mathrm{BC}(5.2 \%) 410 \mathrm{BC}\end{array}$ \\
\hline Jülich-C5 & NZA-1 1518 & unit $7 \mathrm{a}$ & charcoal & $2075 \pm 55$ & $\begin{array}{l}350 \mathrm{BC}(2.9 \%) 320 \mathrm{BC} \\
210 \mathrm{BC}(92.5 \%) 60 \mathrm{AD}\end{array}$ \\
\hline Jülich-C1 & NZA-11239 & just below unit 7 & root fragments & $1550 \pm 60$ & $400 \mathrm{AD}(95.4 \%) 640 \mathrm{AD}$ \\
\hline Jülich-C2 & NZA-1 1245 & just below unit 7 & charcoal & $2205 \pm 60$ & $400 \mathrm{BC}(95.4 \%) 100 \mathrm{BC}$ \\
\hline Jülich-C6 & NZA-1 1252 & just below unit 7 & charcoal & $2130 \pm 60$ & $370 \mathrm{BC}(95.4 \%) 10 \mathrm{AD}$ \\
\hline Jülich-C9 & NZA-1 1517 & top unit 6 & charcoal & $1820 \pm 60$ & $60 \mathrm{AD}(95.4 \%) 390 \mathrm{AD}$ \\
\hline
\end{tabular}


age (J. Poblome, pers. comm.), in this unit. The radiocarbon ages are difficult to interpret in detail. In units 6 and 7, the age profile seems to be inverted, but we believe that this is due to the particular depositional history (two phases of solifluction) of these units. Samples C2 (400 - 100 cal. BC) and C6 (370 cal. BC -10 cal. AD) were taken from what are thought to be the youngest loess deposits preserved in the trench. They represent the organic matter that was present in the top of unit 6 before solifluction took place. Sample $\mathrm{C} 5$ ( $350 \mathrm{cal}$. BC $-60 \mathrm{cal}$. AD) in unit $7 \mathrm{a}$, which is very close in age to samples $\mathrm{C} 2$ and $\mathrm{C} 6$, represents organic matter from the top of unit 6 as well, but which was incorporated in unit $7 \mathrm{a}$ during the first phase of solifluction. Sample C1 was found just below unit $7 \mathrm{a}$, but it consisted of root fragments that must be associated with a surface higher up in the stratigraphy, possibly the horizon between units $7 \mathrm{a}$ and $7 \mathrm{~b}$. This is consistent with its younger age (400640 cal. AD). We thus speculate that this sample postdates at least unit $7 \mathrm{a}$, which might then be age-bracketed between $400 \mathrm{cal}$. BC and $640 \mathrm{cal}$. AD. The ages obtained from samples C7 (800 - 150 cal. BC), C8 $(830-410 \mathrm{cal}$. BC) and C4 (3030 - $2620 \mathrm{cal}$. BC), more or less from the base of unit $7 \mathrm{~b}$, are all significantly older than those from unit $7 \mathrm{a}$. This apparent discrepancy is explained by the interpreted deposition of unit $7 \mathrm{~b}$ during a second phase of solifluction, involving originally deeper loess beds than during the first phase. Sample C9 $(60-390 \mathrm{cal}$. AD) does not fit our interpretation, but has not been taken into account because it is located in the truncated part of unit 6 , and thus not in a continuous vertical sequence with the other samples. Sample C3 (1670 cal. AD modern), finally, was taken from the lower part of a buried A-horizon (unit 8), just downslope of the interpreted position of F6. It could be the result of recent contamination, but part of its $2 \sigma$-range also spans the $17^{\text {th }}$ and $18^{\text {th }}$ century. The age bracket for unit $7 \mathrm{~b}$ is thus rather loosely determined between 400 cal. AD (if our interpretation of $\mathrm{C} 1$ is correct) and the present.

We also took some samples from the $\mathrm{Mn} / \mathrm{Fe}$-band in unit 6 for $U / T h$ dating. This method has proven very successful to date speleothems (Quinif, 1990), but its application on $\mathrm{Fe}$ - and $\mathrm{Mn}$-concretions is still very experimental. The position of the samples is shown in Fig. 3, and the results obtained by the Centre d'Etudes et de Recherches Appliquées au Karst (CERAK) are summarised in Table 2. As there was a problem with the retrieval of $U$ from sample UTh1 (Y. Quinif, pers. comm.), this sample can be rejected. The other samples show good geochemical agreement, supporting a common origin. However, the rather low ${ }^{230} \mathrm{Th} /{ }^{232} \mathrm{Th}$ ratios imply that the $\mathrm{Mn} / \mathrm{Fe}$ system was not geochemically closed. The obtained ages may therefore be over- or underestimated, and can only be used as a broad estimate. Considering the experimental status of the application of the U/Thmethod to date $\mathrm{Mn} / \mathrm{Fe}$-concretions in soils, we believe the OSL-dates found by LKP-2001 for the host sediment to be more reliable to age-bracket fault activity.

In summary, we conclude that the combination of OSL and radiocarbon dating gives us relatively good age control for units 6 and 7 , but is not sufficient to constrain the age of all faulting events. A very important result is the very young, possibly historical, age obtained for unit 7 . This is in disagreement with LKP-2001, who consider that the extensive solifluction (which resulted in deposition of units $7 \mathrm{a}$ and $7 \mathrm{~b}$ ) took place during the period of loess deposition, i.e. during the Weichselian.

\section{Description of the fault zone}

The main fault zone consists of at least five individual fault strands (F1, F2, F3, F4 and FZ5, labels conforming with LKP-2001) (Fig. 3). The presence of a sixth fault, F6, is suggested, but could not be proven. Another fault may be located further upslope (fault F0 in LKP-2001), but is not considered in this study. With the exception of $F 1$, which is located a few meters NE of the trench section we mapped, all faults displace the prominent gravel of units 4 and 5 , as well as the overlying stratified loess of unit 6 . Below, we describe the evidence for each fault separately.

Fault F2 dips $75^{\circ} \mathrm{SW}$, juxtaposes different sand units below the gravel (units 1 and 2 in the footwall against unit 3 in the hanging wall), and displaces bot-

Table 2. Experimental U/Th-datings from Jülich trench. Uncertainty margins are given as $1 \sigma$.

\begin{tabular}{|c|c|c|c|c|c|c|}
\hline Sample ID & $\begin{array}{l}\text { U content } \\
(\mathrm{ppm})\end{array}$ & ${ }^{234} \mathrm{U} /{ }^{238} \mathrm{U}$ & ${ }^{230} \mathrm{Th} /{ }^{234} \mathrm{U}$ & ${ }^{230} \mathrm{Th} /{ }^{232} \mathrm{Th}$ & $\begin{array}{l}{ }^{234} \mathrm{U} /{ }^{238} \mathrm{U} \\
\text { at } \mathrm{t}=0\end{array}$ & Age (ka) \\
\hline UTh1 & $0.599 \pm 0.031$ & $1.218 \pm 0.078$ & $0.845 \pm 0.091$ & $0.70 \pm 0.08$ & 1.363 & $182[+73 /-42]$ \\
\hline UTh2 & $0.824 \pm 0.139$ & $0.958 \pm 0.131$ & $0.584 \pm 0.104$ & $0.532 \pm 0.004$ & 0.945 & $96[+40 /-26]$ \\
\hline UTh4 & $0.788 \pm 0.008$ & $0.987 \pm 0.012$ & $0.522 \pm 0.023$ & $0.47 \pm 0.02$ & 0.984 & $80.3[+5.5 /-5.2]$ \\
\hline UTh5 & $0.764 \pm 0.013$ & $1.227 \pm 0.020$ & $0.412 \pm 0.012$ & $1.03 \pm 0.03$ & 1.266 & $56.5[+2.2 /-2.2]$ \\
\hline
\end{tabular}


tom and top of the gravel units 4 and 5 about $60 \mathrm{~cm}$. Near the trench bottom, F2 has developed a rather broad gouge zone with abundant shear structures in clay derived from units 1 and 2 . Within the gravel units, the fault is characterised by a narrow zone of aligned pebbles, passing into a slightly diverging pattern of sharply defined fault planes within the stratified loess. Internal strata within the loess unit show the same offset as the top of the underlying gravel, without any indication of growth faulting. The faulting history of F2 was thus highly episodic: important activity during the late Pliocene and early Quaternary, followed by a long (more than $1.5 \mathrm{Ma}$ according to LKP-2001) period of inactivity during deposition of units 4,5 , and at least the part of unit 6 that is preserved at this location. Because F2 is cut by the plough zone, the timing of the most recent displacement cannot be better constrained than younger than $43.4 \pm 12.6 \mathrm{ka} \mathrm{BP}$ (youngest OSL-date of the loess unit). For the same reason, any associated colluvial wedge and/or event horizon that could attest the coseismic nature of this fault movement has been lost as well.

Fault F3 consists of two en échelon branches, dipping $75^{\circ} \mathrm{SW}$, and expressed as narrow zones of aligned pebbles within the gravel units. At the contact between gravel and loess deposits, F3 splits into two sharp fault lines with almost equal offset. Displacement at the base of the lower gravel (unit 4) is about $40 \mathrm{~cm}$, but only $30 \mathrm{~cm}$ for the base and top of the upper gravel (unit 5), as well as for horizons within the overlying stratified loess, indicating a period of minor activity during deposition of unit 4 . As with F2, there is no evidence of growth faulting, and the most recent activity post-dates deposition of the loess preserved at this location. Again, the minimum age of this activity cannot be determined due to truncation by the plough zone. The same age constraint as for F2 (younger than $43.4 \pm 12.6 \mathrm{ka} \mathrm{BP}$ ) thus applies to the timing of the most recent fault displacement on F3. However, the observation that F3 is unaffected by the solifluction process responsible for downslope bending of an adjacent ice-wedge cast (see earlier), indicates that it is probably younger than the main phase of solifluction, tentatively dated younger than $400 \mathrm{cal}$. AD. In any case, these geometric relations imply that the activity of F3 is younger than on faults F4 and FZ5 (see below). Probably F2 post-dates the solifluction as well, but this is more difficult to ascertain due to its position further upslope.

F4 is a near-vertical fault, the upper part of which is overturned towards the SW. At the inflection point, a sidebranch splits off from F4, extending straight upwards at an angle of $\pm 70^{\circ} \mathrm{SW}$. F4 is again charac- terised by a narrow zone of aligned pebbles within the gravel, and as a sharp, singular line in the stratified loess unit. At least three periods of activity are discerned after deposition of the gravel units 4 and 5. A first phase of (minor) activity is indicated by the different amounts of displacement for the top of unit 5 (around $90 \mathrm{~cm}$ ) and for the internal stratification within the overlying loess unit 6 (only $70 \mathrm{~cm}$ ). This activity most likely took place during the initial deposition of the stratified loess, because the bottom part of this unit is thicker and displays a slight wedgeshape downslope of F4 (note for instance the 'downlap' of loess horizons against the underlying gravel around $49-50 \mathrm{~m}$ in Fig. 3). The well-defined $\mathrm{Mn} / \mathrm{Fe}-$ band within unit 6 is displaced $70 \mathrm{~cm}$ as well: it is in direct contact with the gravel in the footwall of F4, but separated $\pm 20 \mathrm{~cm}$ from this unit in the hanging wall. This indicates that $\mathrm{F} 4$ was inactive in the period between deposition of unit 6 and subsequent development of the $\mathrm{Mn} / \mathrm{Fe}$-band. The main branch of $\mathrm{F} 4$ is overturned to the SW; its upper termination could not be traced as it is obscured by soil development, but it does not affect the base of unit $7 \mathrm{~b}$ which is incising into unit 6 at this location. The main activity of F4 $( \pm 70 \mathrm{~cm})$ thus post-dates development of the $\mathrm{Mn} / \mathrm{Fe}$-band (no date available, but necessarily younger than $43.4 \pm 12.6 \mathrm{ka} \mathrm{BP}$ ), and is sealed by the solifluction event that caused overturning of F4 and also resulted in deposition of the colluvial loess of unit $7 \mathrm{~b}$ (inferred to be younger than $400 \mathrm{cal}$. AD), as explained in more detail above. Finally, a more recent reactivation of $\mathrm{F} 4$ is represented by the sidebranch, which shows only $10 \mathrm{~cm}$ of offset and is straight and unaffected by solifluction. This sidebranch is associated with a high concentration of plant roots and extends to the base of the plough zone, in which it continues as a bundle of anastomosing cracks up to the ground surface. These surface cracks suggest that at least part of the reactivation is taking place at the present day, and can therefore be considered as anthropogenic, as will be discussed in a separate section.

Fault zone FZ5 accommodates the largest fault displacements observed in the trench. FZ5 consists of a fan of faults with centimetric to decimetric offsets diverging upward from the spot where the thick gravel of unit 4 is displaced below the trench bottom. This geometry suggests that these faults mainly compensate for warping of the underlying gravel unit, which is exceptionally large compared to the other faults. The small faults probably coalesce into a single fault below the trench bottom, but due to rising groundwater we could not observe this master fault, hence the name FZ5. A hand boring in the downthrown block (Fig.3) indicates that the total displacement of the 
base of unit 6 is at least $5 \mathrm{~m}$, proving that FZ5 is undeniably the largest fault affecting the loess deposits in the trench. Its position also coincides with the most pronounced anomaly on an electric resistivity profile measured prior to trenching (see Fig. 3 in LKP2001). Within the stratified loess unit, the small faults of FZ5 are highlighted by the sharp displacements of a black-and-brown $\mathrm{Mn} / \mathrm{Fe}$-band. The offset of this band is the same as that of the internal bedding of the loess unit (at least where both are visible), indicating that no movement occurred between deposition of these loess strata and post-depositional development of the $\mathrm{Mn} / \mathrm{Fe}$-band. The total displacement of this band is at least $140 \mathrm{~cm}$ on the trench wall, but possibly $390 \mathrm{~cm}$ if our correlation with a similar horizon in the hand boring is correct. Thickening of the loess below the $\mathrm{Mn} / \mathrm{Fe}$-band in the borehole is evidence of earlier faulting during deposition of this unit, but it is not possible to identify different faulting episodes. The relation between FZ5 faults and the base of the overlying colluvial loess of unit $7 \mathrm{~b}$ is complex. Not all faults can be traced that far upward (due to obliteration by soil development), but some of them are clearly overturned towards the SW (similar to F4) and truncated at this stratigraphic contact (Fig. 3, near 51.5 and $52.5 \mathrm{~m}$, Fig. 4).

As in most studies of active faulting (Pantosti et al., 1993; McCalpin et al., 1996), we interpret this unconformity as an event horizon, indicative of past coseismic surface rupturing. The main activity of FZ5 can thus be constrained between development of the $\mathrm{Mn} / \mathrm{Fe}$-band in unit 6 (younger than $43.4 \pm 12.6 \mathrm{ka}$ $\mathrm{BP}$ ) and deposition of unit $7 \mathrm{~b}$ (inferred to be younger than 400 cal. AD). Two branches of FZ5 displace the base of unit $7 \mathrm{~b}$ as well, by 20 and $2 \mathrm{~cm}$ respectively (Fig. 4b), and continue upward as diffuse, but narrow bundles of anastomosing cracks. A gravel body at the top of unit $7 \mathrm{~b}$ bears some resemblance to a colluvial wedge, but we do not favour such interpretation, as there is not enough offset to account for (only 20-30 $\mathrm{cm}$ at the base of unit $7 \mathrm{~b}$ ), and also because the gravel is situated too far upslope (49.5-51 m in Fig. 3) and reappears further downslope $(54.5-56.5 \mathrm{~m}$ in Fig. 3 ). As the crack bundles extend up to, and in some cases even into the plough zone, we relate them entirely to reactivation of FZ5 faults due to modern, induced fault motion. This also explains the appearance of unit 9 below the plough layer in the area where the cracks are most dense (see later).

Fault F6, finally, is a fault which could not be well observed due to intense soil development in the downslope part of the trench. Its presence is suggested by several anomalous observations in alignment with each other (Fig. 3): (1) interruption and \pm 80 $\mathrm{cm}$ displacement of the top of a calcitic lens within unit 6 , (2) presence of a vague and steeply dipping crack within unit 6 , filled with material from the overlying unit 7 , (3) dip reversal of internal stratification of unit 6 left and right of the supposed fault, (4) strong and abrupt incision of unit 7 (> $135 \mathrm{~cm}$ total; $\pm 50 \mathrm{~cm}$ on the steep edge of unit $7 \mathrm{~b}$ in continuation with the crack in unit 6), (5) appearance of unit $7 \mathrm{a}$, and (6) appearance of a \pm 25 -cm-thick, khakicoloured soil (unit 8), reminiscent of a buried A-horizon, well below the plough zone. From these observations, we tentatively interpret two separate phases of fault activity. A first displacement $(>60 \mathrm{~cm}$ ) would have triggered a first phase of solifluction and ensuing deposition of the colluvium of unit $7 \mathrm{a}$, which is dated between $400 \mathrm{cal}$. BC and $640 \mathrm{cal}$. AD. The second fault movement is inferred to have displaced the base of unit $7 \mathrm{~b}(50 \mathrm{~cm})$, while the buried A-horizon of unit 8 might represent the associated colluvial wedge. If these interpretations are correct, then F6 would accommodate the most recent fault activity in the trench record, apart from the modern anthropogenic reactivation. The tentative age bracket for this activity is between $400 \mathrm{cal}$. $\mathrm{AD}$ and $1670 \mathrm{cal}$. $\mathrm{AD}$ to present (age of sample C3).

\section{Summary of faulting history}

The stratigraphic record exposed in the trench near Jülich clearly evidences the Quaternary activity of the Rurrand fault at this site. The two prominent gravel layers (units 4 and 5) provide a reference level to tie the tectonic deformation of the Rurrand fault to. Considering the large age $(>1 \mathrm{Ma})$ inferred for these units, any deformation predating or contemporaneous with these gravel units (e.g. F1, the set of small faults affecting unit 1 , and the earlier activity of F2) is irrelevant for the purpose of paleoseismology, as pointed out by LKP-2001. However, we find that the major part of the deformation we observed in the trench post-dates the gravel units. The total vertical displacement on the fault zone since deposition of the gravel of unit 5 is at least $700 \mathrm{~cm}$, divided over the different fault strands $(\mathrm{F} 1: 0 \mathrm{~cm}, \mathrm{~F} 2: 60 \mathrm{~cm}, \mathrm{~F} 3: 30$ $\mathrm{cm}, \mathrm{F} 4: 105 \mathrm{~cm}, \mathrm{FZ} 5:>500 \mathrm{~cm}, \mathrm{~F} 6: 110 \mathrm{~cm}$ ?). Independently, the near-horizontal attitude of the top of this gravel terrace (Figs. 2 and 3, see also Fig. 6 of LKP-2001) indicates that most of the topographic offset from $41 \mathrm{~m}$ downward along the trench profile is the result of later fault activity. What is more, a considerable amount of fault displacement $(\mathrm{F} 2: 60 \mathrm{~cm}$, F3: $30 \mathrm{~cm}, \mathrm{~F} 4: 70+10 \mathrm{~cm}, \mathrm{FZ} 5:$ at least $140 \mathrm{~cm}, \mathrm{~F} 6$ : $110 \mathrm{~cm}$ ?) extends up to the top of the stratified loess (unit 6) or higher. This includes about $40 \mathrm{~cm}$ of mod- 


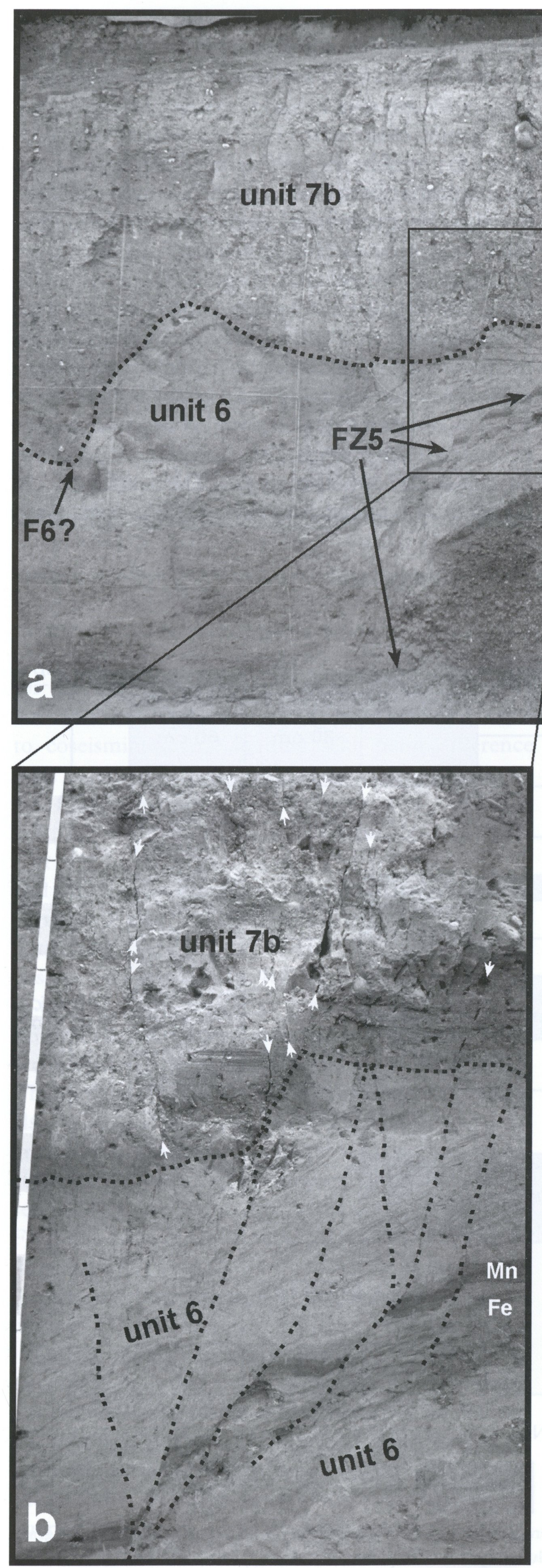

Fig. 4. Relation between colluvium of unit $7 \mathrm{~b}$ and FZ5: (a) general view of colluvial loess unit $7 \mathrm{~b}$ in the zone of the main fault FZ5, location indicated in Fig. 3; (b) photograph showing (mostly bent) faults truncated by the base of unit $7 \mathrm{~b}$, as well as faults that are displacing this contact, continuing upward into diffuse crack bundles. Dotted lines indicate stratigraphic contacts, double-dotted lines indicate fault lines; arrows point to visible cracks. 
ern induced fault motion (see next section), but it indicates that a significant amount of fault activity is younger than $43.4 \pm 12.6 \mathrm{ka} \mathrm{BP}$ (youngest OSL-date of stratified loess).

In the preceding section, we have demonstrated that the faulting activity at the trench site was not continuous, but clearly episodic. The history of activity inferred for each fault strand since deposition of the main gravel units 4 and 5 is summarised in Fig. 5 .

Due to the incomplete stratigraphy, a lot of uncertainties remain, but the overall picture is that the history of faulting was complex, and that different fault strands have been active at different times. Due to truncation of faults $\mathrm{F} 2$ and F3, the relative timing of the most recent activity on these faults with respect to F4 and FZ5 cannot be determined straightforwardly. However, from their overturned shape, it can be inferred that the most recent displacements on FZ5 and on the main branch of $\mathrm{F} 4$ are older than, or contemporaneous with, a phase of solifluction that remobilised the stratified loess of unit 6 . The small sidebranch of F4 and faults F3 and F2 cut straight through the loess strata, and their activity is thus inferred to post-date the solifluction phase. In combination with the absence of growth faulting features in the same loess unit, these geometrical relations argue for a highly episodic faulting activity.

The thick colluvial loess of unit 7 is of particular interest for the paleoseismological analysis of the fault zone. We interpret it as the product of solifluction and related slope failure of the underlying stratified loess, in which it is deeply incised. Extensive solifluction in the area is generally attributed to intensified slope processes under periglacial conditions during the Saalian and Weichselian glacials. The solifluction observed at the trench site, however, was more likely

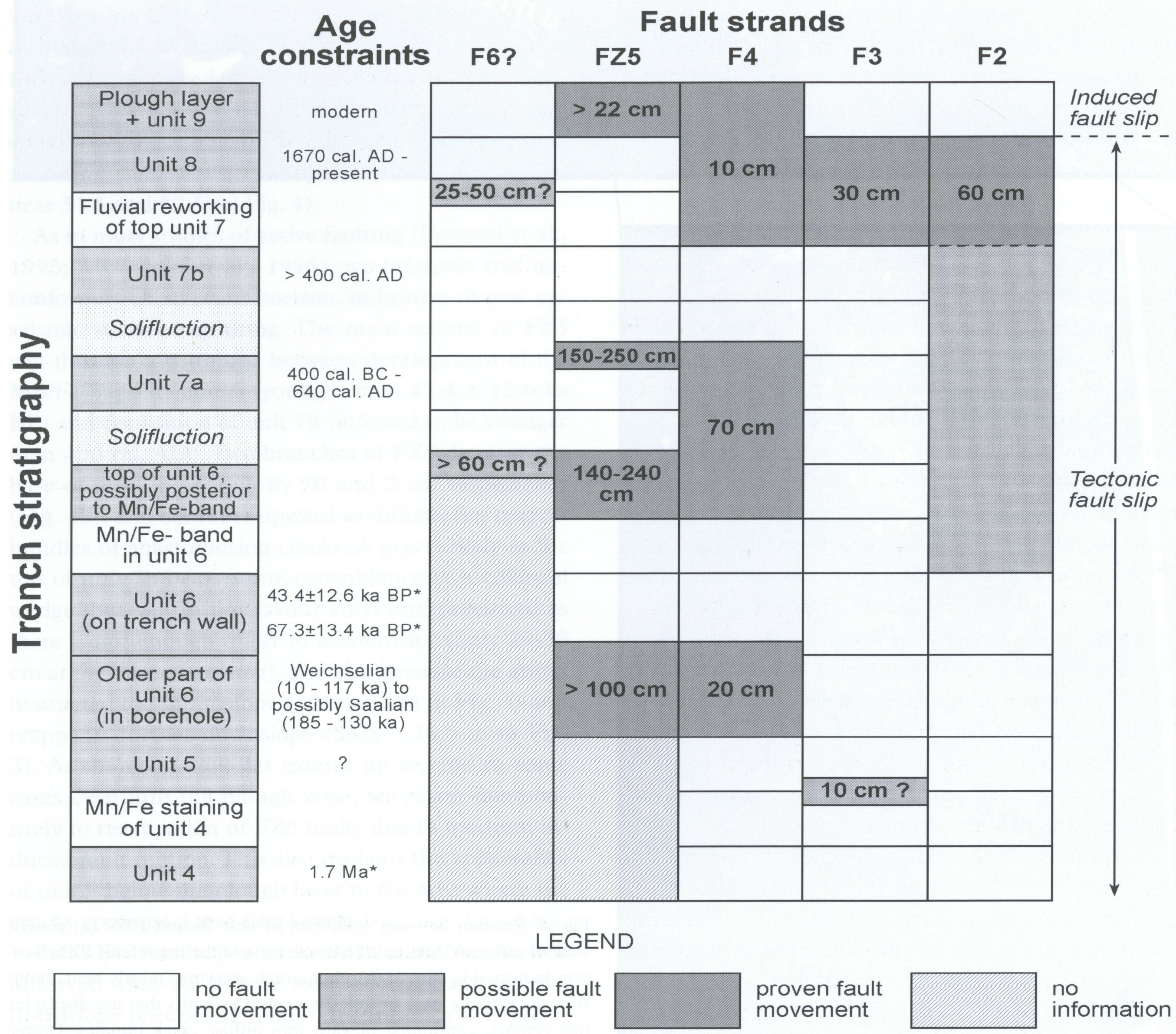

Fig. 5. Table summarising possible time windows for the activity of different fault strands in Jülich trench since deposition of the main gravel terraces. Age constraints marked with ${ }^{\star}$ are from Lehmann et al. (this volume). 
caused by surface faulting. This is suggested by the young age $(<400 \mathrm{cal}$. BC) of the colluvium, obtained from independent dating methods, and by its position, which is controlled by the position of the main fault: over a distance of $5 \mathrm{~m}$, the colluvium incises about $3 \mathrm{~m}$ into the stratified loess of unit 6 . Most of the incision occurs in two distinct steps, one slightly upslope of FZ5, the other coinciding with the inferred position of F6. Downslope of the fault zone, the base of the colluvium abruptly turns horizontal again. We have also shown that the colluvium is divided in two subunits, a lower unit (7a) which is bounded by F6, and an upper unit (7b), which is thicker, contains coarser gravel and extends over the entire reach of the colluvium. These subunits are separated by a thin layer of loess without gravel, which indicates that the colluvium of unit 7 was deposited during two separate phases of solifluction. Combining these observations, we infer that colluvial units $7 \mathrm{a}$ and $7 \mathrm{~b}$ were deposited in response to two surface rupturing events, causing large and abrupt modification of the slope morphology, which triggered solifluction processes and also created the necessary accommodation space for the 'incision' of the resulting colluvium. Units $7 \mathrm{a}$ and $7 \mathrm{~b}$ would thus represent colluvial wedges related to coseismic surface faulting. The main difference with more classical colluvial wedges identified in active faulting studies (e.g. McCalpin et al., 1996), is that they were deposited by different slope processes that acted much more rapidly. The bases of units $7 \mathrm{a}$ and $7 \mathrm{~b}$ would then correspond to event horizons or earthquake unconformities (Pantosti et al., 1993), as illustrated by truncation of most FZ5 faults by the base of unit $7 \mathrm{~b}$ (see Fig. 4b). We relate the colluvium of unit $7 \mathrm{a}$ to a first surface rupture involving at least F6, whereas unit $7 \mathrm{~b}$ was most likely associated with a second and larger surface rupture mainly on FZ5. This fault displays the largest displacements, and is also associated with significant warping of the main gravel unit, which could explain why incision of the colluvium started slightly upslope from the fault itself. The age constraint for the main displacement on F4 is too large to determine whether it occurred before, between or together with these two events.

Thus, a coherent sequence of faulting events can be derived, as shown in Fig. 6.

During initial deposition of the stratified loess of unit 6 (> $67.3 \pm 13.4 \mathrm{ka}$ BP OSL, possibly up to Saalian) a $20-\mathrm{cm}$ displacement occurred on F4 and an unknown number of surface faulting events responsible for at least $110 \mathrm{~cm}$ of offset on FZ5 (not shown in Fig. 6). After deposition of unit 6 and subsequent development of the $\mathrm{Mn} / \mathrm{Fe}$-band in this unit (< $43.4 \pm 12.6 \mathrm{ka}$ BP OSL), at least two surface ruptur- ing events occurred, involving three fault strands (F4, FZ5 and F6), and resulting in solifluction and deposition of the colluvial units $7 \mathrm{a}$ and $7 \mathrm{~b}$. It is not clear at what stage the $70-\mathrm{cm}$ displacement of $\mathrm{F} 4$ occurred (we only know that it pre-dates unit $7 \mathrm{~b}$ ), and if FZ5 was active during only one event, or maybe twice. The first phase of solifluction generated the colluvium of unit 7a, and involved F6 (> $60 \mathrm{~cm}$ displacement), and probably another fault further upslope (FZ5 and/or F4). The age of this unit is bracketed by radiocarbon datings between $400 \mathrm{cal}$. BC and (tentatively) 640 cal. AD. This was followed shortly (as witnessed by the veneer of sediment between units $7 \mathrm{a}$ and $7 \mathrm{~b}$ ) afterwards by the largest surface faulting event in the trench record (at least $140 \mathrm{~cm}$, possibly $250 \mathrm{~cm}$ ), which involved at least FZ5, and possibly also F4. This event is thought to have occurred close to $400-$ 640 cal. AD. It triggered a second, more extensive phase of solifluction, which was responsible for bending and overturning of F4 as well as of the fault strands of FZ5 itself. The solifluction culminated in deposition of a thick unit of colluval loess (unit $7 b$ ), deeply incising into unit 6 and truncating the freshly created FZ5 faults. After this major event, moderate displacements occurred (possibly simultaneously) on F2 $(60 \mathrm{~cm}), \mathrm{F} 3(30 \mathrm{~cm})$ and possibly F4 (max. 10 $\mathrm{cm}$ ), which all remained unaffected by the extensive solifluction. These faulting events would thus be younger than $400 \mathrm{cal}$. AD. Their minimal age cannot be determined as the associated event horizons have not been preserved, probably due to anthropogenic surface modification. A final faulting event $(25-50$ $\mathrm{cm}$, not shown in Fig. 6) may have occurred on F6, displacing unit $7 \mathrm{~b}$ and possibly associated with a small colluvial wedge (unit 8), from which one radiocarbon date of $1670 \mathrm{cal}$. AD to present was obtained.

\section{Expression of modern, man-induced differential ground subsidence}

At present, most of the German part of the RVG is affected by rapid subsidence induced by regional groundwater lowering necessary for the 300-m-deep, open-cast browncoal mines in the area. One mine, Tagebau Hambach, is located only a few hundreds of meters from the trench site, on the footwall side of the Rurrand fault. Since about 1960, the region around the trench site has subsided 0.5-1.0 m, and the area to the east even up to $3 \mathrm{~m}$ (Schaefer, 1999). Due to different thicknesses of compacting clay and lignite layers, subsidence is differential across the Quaternary faults in the area. As a result, the Rurrand fault is experiencing slow, aseismic slip of about 10 $\mathrm{mm} / \mathrm{a}$ on its upper few hundreds of meters, which is 


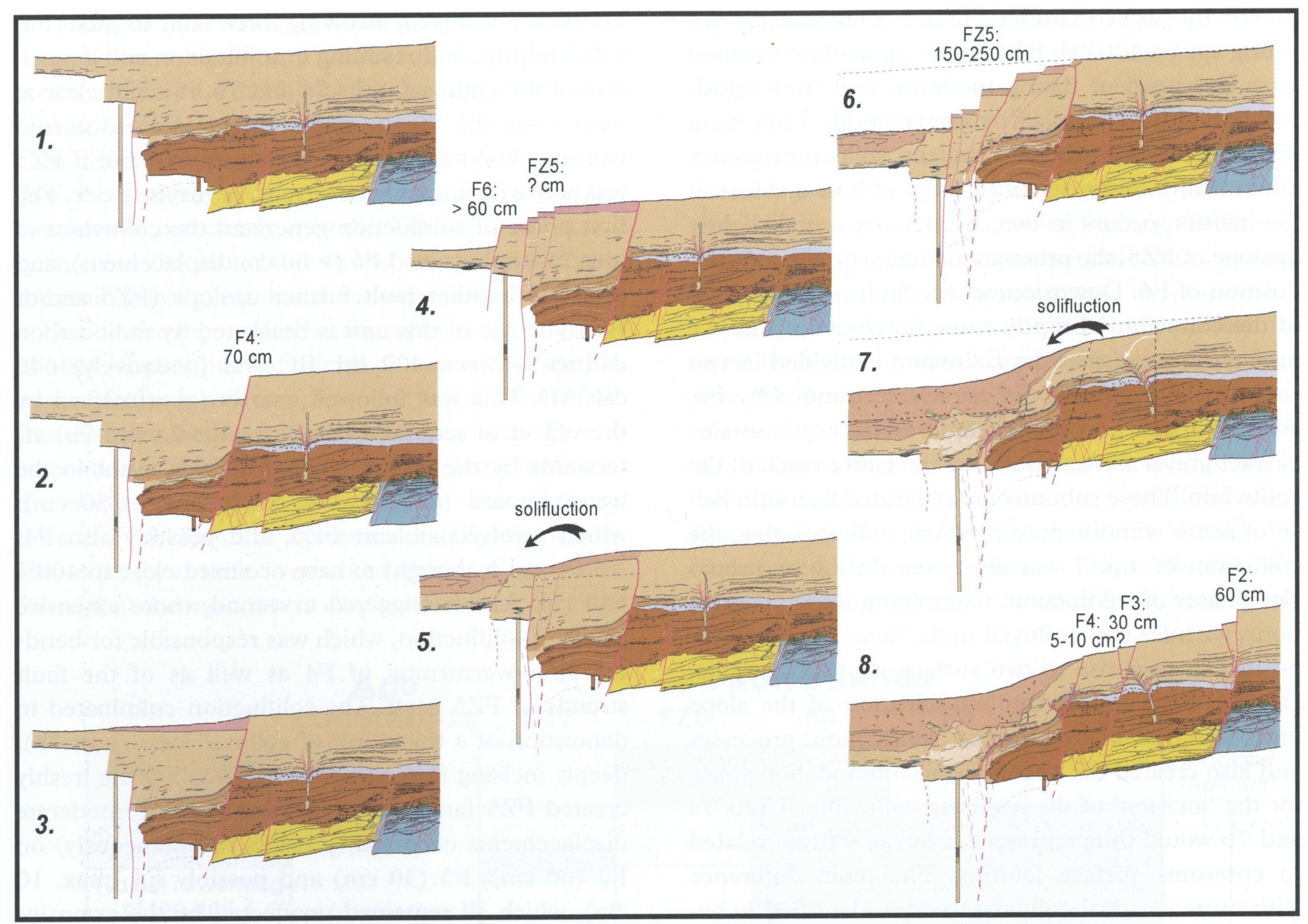

Fig. 6. Tentative partial reconstruction of faulting history at Jülich-Stallbusch linking the extensive solifluction phases to large surface faulting events: (1) situation after deposition of stratified loess (unit 6) and development of $\mathrm{Mn} / \mathrm{Fe}$-band in this unit; (2) moderate displacement on F4; as the timing of this displacement is not well constrained relative to the large faulting events on F6 and FZ5, this event could also have occurred together with steps 4 or 6 , or in between; (3) deposition of colluvial wedge related to F4; this colluvium has probably been destroyed by later solifluction; (4) large displacement on F6 and another fault upslope, probably FZ5; (5) solifluction and deposition of colluvium (unit 7a); (6) large displacement on FZ5, master fault branching upward into several fault planes; (7) extensive solifluction of stratified loess, resulting in overturning of F4 and an ice-wedge-like feature further upslope, and in the deposition of thick colluvium (unit 7b); (8) moderate displacement on F2, F3, and possibly F4, not necessarily simultaneously.

unrelated to any tectonic deformation. This induced superficial slip is expressed by the new creation of small, but pronounced scarplets along some sections of its surface trace (Schaefer, 1999). A 35-cm-high scarplet can be observed $1 \mathrm{~km}$ away from the trench (LKP-2001), but not at the trench site proper; an artificially elevated road adjacent to the site, however, displays a narrow zone of cracks, and needs to be repaired regularly.

The question is thus raised how this ongoing, induced, creep-like fault motion is reflected in the trench record, and if it can be distinguished from the older, tectonic movements. In the fault description we described evidence of several cracks extending from F4 and FZ5 into the plough layer and even up to the surface (Fig. 3). The ground crack connecting with F4 was open at surface (Fig.7b and c), and could be traced laterally for a few meters, in the general direction of the road cracks further away. These cracks are most likely the result of the modern, induced movement of the Rurrand fault. They were preserved thanks to an extended period ( \pm 1 year) of non-cultivation of the site. The crack connects with the sidebranch of $\mathrm{F} 4$, which corresponds to a $10-\mathrm{cm}$ reactivation of an older fault plane that was overturned by solifluction (Figs. 3 and 6). We are not sure, however, if these $10 \mathrm{~cm}$ are entirely due to induced motion, because there is no clear increase in thickness of the plough zone downslope of the fault.

The other cracks are concentrated in several bundles in the colluvial loess of unit $7 \mathrm{~b}$ above FZ5, and at least one of them extends up to the ground surface. These anastomosing fissures are visible both in the vertical (Fig. 4b) and in the horizontal plane (Fig. $7 \mathrm{a}$ ), are distributed over a 3-4 $\mathrm{m}$ wide zone, and are parallel to the general fault direction. In this zone, a 30-cm-thick, blue-gray soil appears below the plough layer in the area where the cracks are most dense 

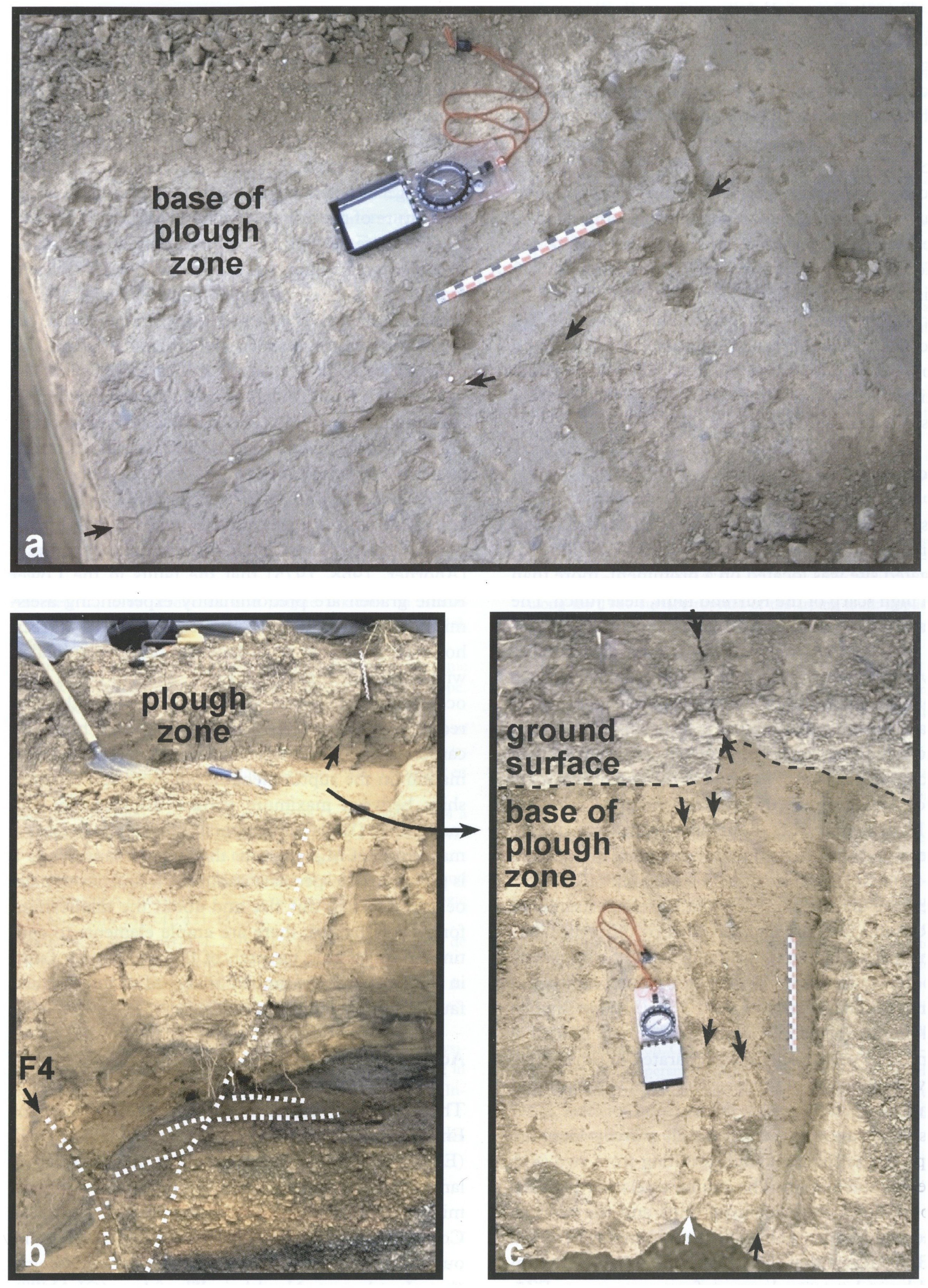

Fig. 7. Aspect of modern induced fault slip in Jülich trench: (a) horizontal slice near the base of the plough zone of one of the crack bundles in Fig. 4b; (b) Straight sidebranch of fault F4 continuing as an open crack (see arrow) up to the ground surface; dotted lines indicate stratigraphic levels, double-dotted lines indicate fault lines (c) bird's eye view of b; dashed line indicates vertical cliff ( $\pm 40 \mathrm{~cm}$ high) between the ground surface and the base of the plough zone. Arrows point to visible cracks. Location of $b$ is indicated in Fig. 3. 
(unit 9, Fig. 3). We interpret it as the lower parts of the initial plough zone that have subsided below the plough reach. Figure $4 \mathrm{~b}$ shows how two crack bundles connect with singular fault planes below, displacing the base of unit $7 \mathrm{~b}$ by 2 and $20 \mathrm{~cm}$, respectively. This suggests that the anastomosing fissures are the expression of upward propagation of FZ5 faults by induced, superficial fault creep into the previously unfaulted colluvial loess. Although the induced fault movement thus appears to be distributed over a 4-5 $\mathrm{m}$ wide zone, we infer that half of this movement (20 $\mathrm{cm}$ ) is taken up on a single crack bundle, and possibly up to $10 \mathrm{~cm}$ on the crack extending from $\mathrm{F} 4$. We found no evidence that the induced fault slip would be concentrated on F2, as put forward by LKP-2001. Detailed geodetic monitoring is presently carried out to resolve this issue (see LKP-2001).

\section{Conclusions}

A first trench has been excavated for paleoseismological analysis in the German part of the RVG. The investigated site was located on a prominent, more than 10-m high scarp of the Rurrand fault, near Jülich. The Rurrand fault was exposed as a complex zone of several SW-dipping, normal fault strands, situated halfway the main escarpment. These faults displace the base of a stratified loess layer of Weichselian (and probably also Saalian) age by more than $7 \mathrm{~m}$. At least $310 \mathrm{~cm}$, and if our interpretations are correct even $670 \mathrm{~cm}$, of fault offset extends to the top of this loess unit or higher, and is thus younger than $43.4 \pm 12.6$ ka BP. Excluding the about $40 \mathrm{~cm}$ that are due to modern, induced fault motion, this corresponds to a long-term fault slip rate of $0.05-0.20 \mathrm{~mm} / \mathrm{a}$.

We have shown evidence that different strands of the Rurrand fault are characterised by different faulting histories, and that the fault activity was clearly episodic. We found no evidence of growth faulting in the trench. The activity of F2, F3 and the sidebranch of F4 on the one hand, and that of the main branch of F4 and FZ5 on the other, are separated in time by extensive solifluction of the loess deposits, which caused downslope bending and overturning of the latter faults. Two layers of structureless, gravelly loess are interpreted as the colluvium resulting from two such phases of solifluction. The intimate relation between the position of these colluvial units and the position of the main faults, and their very young age $(<400$ cal. BC) suggest that the solifluction events were triggered by at least two large surface ruptures on FZ5, F6 and possibly F4. Our stratigraphic control is not sufficient to determine exactly which fault strands moved at what time, but the first event is tentatively dated between $400 \mathrm{cal}$. BC and $640 \mathrm{cal}$. AD, and the second event, which was even larger, between $400 \mathrm{cal}$. $\mathrm{AD}$ and 1670 cal. AD to present. The faults F2, F3 and the sidebranch of F4 have not been affected by solifluction, and are thus younger. Unfortunately, these fault planes are truncated by the plough zone, which makes it impossible to determine their minimum age of activity, and also to confirm the coseismic nature of the displacements they show.

Finally, we have observed bundles of anastomosing cracks extending upward from F4 and FZ5 into unfaulted strata and in some cases even up to the ground surface. We interpret these cracks as the expression of modern, superficial fault slip, induced by regional groundwater lowering for mining purposes. Possibly this faulting character can be considered as a modern analogue of long-term aseismic fault slip, the expression of which has rarely been described for unconsolidated surface deposits.

The evidence we have presented here is compatible with a scenario of coseismic faulting, though perhaps not conclusive, and challenges earlier hypotheses (Ahorner, 1968, 1975) that the faults in the Lower Rhine graben are predominantly experiencing aseismic fault creep. If our interpretations are correct, however, a number of surface-rupturing earthquakes with displacements up to $150-250 \mathrm{~cm}$ could have occurred in a relatively short span of time in the very recent past (around $2 \mathrm{ka} \mathrm{BP}$ ), as indicated by radiocarbon and OSL datings. We don't have reliable information on the rupture length, but empirical relationships between maximum surface displacement and magnitude (Wells \& Coppersmith, 1994) suggest a magnitude of $M_{W} \approx 6.8$ for the largest event. While it is premature to speculate about the frequency of paleoearthquakes of this size and about the implications for seismic hazard, there are ample elements to continue paleoseismic research of the Quaternary faults in the Lower Rhine graben area, and of the Rurrand fault near Jülich in particular.

\section{Acknowledgements}

This study was carried out in the framework of the Environment and Climate project PALEOSIS (ENV4-CT97-0578) 'Evaluation of the potential for large earthquakes in regions of present-day low seismic activity in Europe', funded by the European Commission. In the first place, we would like to thank our project partners, R. Pelzing from the Geologisches Landesamt Nordrhein-Westfalen (GLANW), and K.-G. Hinzen from the University of Köln, for giving us the opportunity to conduct independent mapping of the trench exposure. We are much obliged 
to T. Camelbeeck for coordinating the project and guiding our research. We enjoyed the cooperation in the field with our GLANW-colleagues, K. Lehmann, U. Dworschak \& S. van de Logt. We appreciated discussions in the field with E. Paulissen (University of Leuven) and K. Atakan (University of Bergen). We are also indebted to W. Schaefer, Rheinbraun company, for showing us the expression of differential ground subsidence related to groundwater extraction in the area. We are grateful to Y. Quinif, Faculté Polytechnique de Mons, Belgium, for the experimental U/Th-dating of our samples, and to M. Van Strydonck (Royal Institute for Cultural Heritage) for dating our radiocarbon samples. Careful reviews by $M$. Meghraoui (Institut de Physique du Globe) and F. Galadini (Consiglio Nazionale delle Ricerche) helped us to improve the structure and content of this manuscript. Finally, we would like to thank P. Pâquet and $R$. Verbeiren for their ongoing support of our research at the Royal Observatory of Belgium.

\section{References}

Ahorner, L., 1968. Erdbeben und jüngste Tektonik im Braunkohlenrevier der Niederrheinischen Bucht. Z. deutsch. Geol. Ges. 118: 150-160.

Ahorner, L., 1975. Present-day stress field and seismotectonic block movements along major fault zones in central Europe. Tectonophysics 29: 233-249.

Ahorner, L., 1994. Fault-plane solutions and source parameters of the 1992 Roermond, the Netherlands, mainshock and its stronger aftershocks from regional seismic data. Geologie en Mijnbouw 73(2-4): 199-214.

Alexandre, P., 1990. Les séismes en Europe Occidentale de 324 à 1259: Nouveau catalogue critique. Publications de l'Observatoire Royal de Belgique, Série Géophysique, Bruxelles, 267 pp.

Alexandre, P., 1994. Historical seismicity of the lower Rhine and Meuse valleys from 600 to 1525: A new critical review. Geologie en Mijnbouw 73(2-4): 431-438.

Alexandre, P. \& Kupper, J.-L ,1997. Le tremblement de terre de 1692. Feuillets de la cathédrale de Liège 28-32: 3-19.

Camelbeeck, T. \& Meghraoui, M., 1996. Large earthquakes in northern Europe more likely than once thought. EOS, Transactions, AGU 77(42): 405,409.

Camelbeeck, T. \& Meghraoui, M., 1998. Geological and geophysical evidence for large paleoearthquakes with surface faulting in the Roer Graben (northwest Europe). Geophysical Journal International 132: 347-362.

Camelbeeck, T., van Eck, T., Pelzing, R., Ahorner, L., Loohuis, L.,
Haak, H.W., Hoang-Trong, P. \& Hollnack, T., 1994. The 1992 Roermond earthquake, the Netherlands, and its aftershocks. Geologie en Mijnbouw 73(2-4): 181-197.

Geluk, M.C., Duin, E.J.Th., Dusar, M., Rijkers, M.H.B., van den Berg, M.W., \& van Rooijen, P., 1994. Stratigraphy and tectonics of the Roer Valley Graben. Geologie en Mijnbouw 73 (2-4): 129141.

Gullentops, F., Paulissen, E. \& Vandenberghe, J., 1981. Fossil periglacial phenomena in NE-Belgium. Biuletyn Peryglacjalny 28: 345-365.

Hinzen, K.-G., Reamer, S.K. \& Rose, T., 2001, this volume. Geomorphological aspects of site selection at the Rurrand Fault for paleoseismological investigations. Submitted to Netherlands Journal of Geosciences (Geologie en Mijnbouw).

Juvigné, E., Haesaerts, P., Mestdagh, H., Pissart, A., and Balescu, S., 1996. Révision du stratotype loessique de Kesselt (Limbourg, Belgique). C. R. Acad. Sci. Paris 323 (IIa): 801-807.

Lehmann, K., Klostermann, J. \& Pelzing, R., 2001, this volume. Paleoseismological investigations at the Rurrand Fault, Lower Rhine Embayment. Submitted to Netherlands Journal of Geosciences (Geologie en Mijnbouw).

Meghraoui, M., Camelbeeck, T., Vanneste, K., Brondeel, M., \& Jongmans, D., 2000. Active faulting and paleoseismology along the Bree fault zone, Lower Rhine graben (Belgium). Journal of Geophysical Research 105: 13809-13841.

McCalpin, J.P. (ed), 1996. Paleoseismology. Academic Press, San Diego, 583 pp.

Pantosti, D., Schwartz, D.P. \& Valensise, G., 1993. Paleoseismology along the 1980 surface rupture of the Irpina fault: implications for earthquake recurrence in the southern Apennines, Italy. Journal of Geophysical Research 98: 6561-6577.

Pelzing, R., 1994. Source parameters of the 1992 Roermond earthquake, the Netherlands, and some of its aftershocks recorded at the stations of the Geological Survey of Northrhine-Westphalia. Geologie en Mijnbouw 73 (2-4): 215-223.

Quinif, Y., 1990. La datation des spéléothèmes (U/Th) appliquée aux séquences sédimentaires souterraines pour une mise en évidence des ruptures paléoclimatiques. Karstologia Mémoires 2: 23-32.

Schaefer, W., 1999. Bodenbewegungen und Bergschadensregulierung im Rheinischen Braunkohlenrevier. Proceedings of the 42. DMV-Tagung, Cottbus, September 1999: 1-10.

Scholz, C.H., 1990. The mechanics of earthquakes and faulting. Cambridge University Press, 439 pp.

Seismic Hazard Working Party, 1993. A review of the seismotectonics of Britain in the context of NW Europe. Report on seismic hazard assessment, Vol. 3J , Nuclear Electric: 135 pp.

van den Berg, M.W., 1994. Neotectonics of the Roer Valley rift system: Style and rate of crustal deformation inferred from syn-tectonic sedimentation. Geologie en Mijnbouw 73 (2-4): 143-156.

Wells, D.L. \& Coppersmith, K.J., 1994. New empirical relationships among magnitude, rupture length, rupture width, rupture area, and surface displacement. Bulletin of the Seismological Society of America 84 (4): 974-1002. 